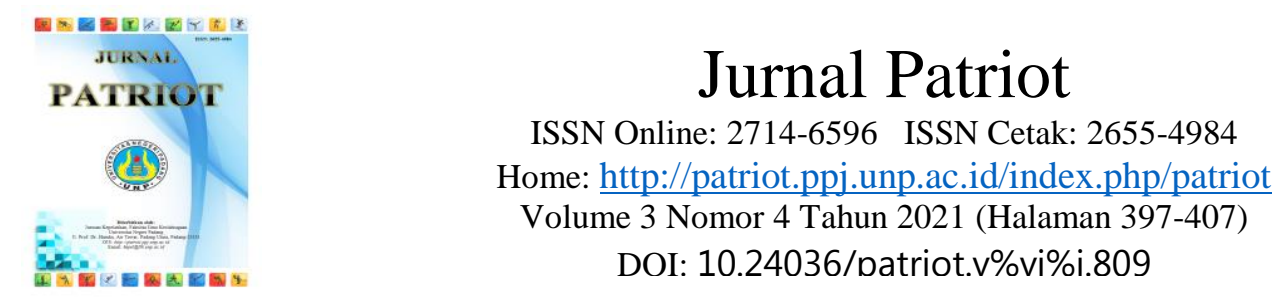

\title{
Analisis Tingkat Konsentrasi Anak Usia 11-13 Tahun Melalui Aktivitas Fisik Olahraga Renang
}

\author{
I Putu Agus Dharma Hita ${ }^{1}$, Doni Pranata ${ }^{2 *}$, Muhammad Efendi $^{3}$ \\ 1,2,3Program Studi Ilmu Keolahragaan, Fakultas Ilmu Keolahragaan, Universitas Negeri \\ Yogyakarta, Indonesia \\ Email Korespondensi: dpranata9710@gmail.com
}

Informasi Artikel:

Dikirim: 7 Agustus 2021 Direvisi: 1 November 2021 Diterbitkan: 26 November 2021

\begin{abstract}
ABSTRAK
Konsentrasi merupakan salah satu faktor yang sangat penting dimiliki oleh setiap individu dalam melakukan aktivitas olahraga, melalui konsentrasi yang baik maka dapat menghasilkan prestasi yang optimal. konsentrasi memiliki makna ialah bagaimana tingkat kesadaran seseorang yang tertuju pada suatu objek pada waktu tertentu. Pada Penelitian berikut bermaksud untuk mengetahui tingkatan konsentrasi anak umur 11- 13 tahun terhadap olahraga renang. Penelitian ini ialah tergolong kedalam jenis penelitian survey dengan desain deskriptif kuantitatif. Penelitian berikut dilaksanakan pada bulan April tahun 2021. Populasi yang digunakan dalam penelitian ini adalah anggota club renang Cimahi Junior Swimming Club yang berusia 11-13 tahun yang berjumlah 15 orang. Teknik sampling yang digunakan dalam penelitian ini yaitu total sampling yaitu sebanyak 15 orang. Instrumen penelitian ini menggunakan angket konsentrasi yang terdiri dari 30 pernyataan. Sebelum digunakan, terlebih dahulu angket tersebut dilakukan uji validitas serta uji reliabilitas menggunakan teknik cronbach's alpha dengan hasil bahwa angket sudah valid dan reliabel. Hasil penelitian ini menunjukan bahwa rata-rata tingkat konsentrasi anak terhadap olahraga renang dalam kategori rendah dengan jumlah 8 orang (54\%).
\end{abstract}

Kata Kunci: Anak; Konsentrasi; Olahraga; Renang

\section{Analysis of the Concentration Level of 11-13 Years Old Children Through Swimming Physical Activity}

\begin{abstract}
Concentration is one of the most important factors possessed by every individual in carrying out sports activities, through good concentration it can produce optimal performance. Concentration has meaning is how a person's level of consciousness is focused on an object at a certain time. In the following study, it is intended to determine the level of concentration of children aged 11-13 years on swimming. This research is classified into the type of survey research with a quantitative descriptive design. The following research was conducted in April 2021. The population used in this study were members of the Cimahi Junior Swimming Club swimming club aged 11-13 years, totaling 15 people. The sampling technique used in this study is a total sampling of 15 people. The research instrument used a concentration questionnaire consisting of 30 statements. Before being used, the questionnaire was tested for validity and reliability testing using the Cronbach's alpha technique with the result that the questionnaire was valid and reliable. The results of this study indicate that the average level of concentration of children on swimming is in the low category with a total of 8 people (54\%).
\end{abstract}

Keywords: Children; Concentration; Sports; Swimming 


\section{PENDAHULUAN}

Aktivitas fisik adalah bagian kegiatan yang sangatlah berguna bagi manusia karena dengan bergbagai manfaat yang dimiliki dalam setiap gerakannya bagi keberlangsungan hidup, adapun beberapa contoh kongkritnya yang banyak kita ketahui dari berbagai literatur dan penelitian sebelumnya. Kegiatan aktivitas fisik membawa manfaat bagi kelancaran peredaran darah, meningkatkan hormon kebahagian, dan merangsang pertumbuhan secara optimal bagi usia anak-anak. Setiap orang diwajibkan untuk melangsungkan aktivitas fisik tanpa ada perbedaan apapun baik usia, gender, dan golongan kerja. Secara tidak langsung aktivitas fisik menggambarkan taraf kesehatan seseorang, apabila seseorang dapat melakukan aktivitas fisik yang begitu lama maka hal ini menggambarkan bahwa sesorang tersebut memiliki daya tahan serta taraf kesehatan yang baik. Aktivitas fisik memiliki definisi secara khusus dapa dikatan adalah proses kegiatan olahraga.

Olahraga sendiri memiliki pengertian ialah olahraga dipenggal menjadi dua suku kata yakni olah dan raga, olah adalah proses bagaimana menggabungkan maupun memodifikasi dalam konteks fisik sedangkan raga adalah segala kegiatan yang erat kaitannya dengan badan. Jika dua suku kata tersebut digabungkan didapatilah pengertian dari olahraga adalah segala bentuk kegiatan dalam proses melakukan, memadukan, memodifikasi gerakan yang dicoba oleh perorangan ataupun golongan dengan tujuan tertentu dan melibatkan semua anggota tubuh (Pranata et al., n.d.). Selaras dengan pernyataan yang dikemukakan diatas, menurut (Yazid et al., 2016) dalam rangka menciptakan manusia yang seutuhnya, sehat serta bugar jasmaninya serta rohaninya yang baik olahraga ialah salah satu wujud aktivitas yang harus dicoba semua orang tanpa terkecuali baik itu dilakukan secara kelompok maupun perorangan. Aktivitas fisik merupakan salah satu perwujudan yang diimplementasikan melalui gerakan anggota tubuh dengan cara memanfaatkan energi yang berasala dari bahan makanan yang dikonsumsi (Sholihin, 2015).

Melalui kegiatan aktivitas fisik yang dilakukan secara optimal, maka hal ini akan memberikan manfaat bagi kebugaran seseorang. Ketika kebugaran seseorang baik, maka hal ini dapat memberikan manfaat yang dapat menghindarkan seseorang mengalami kelebihan secara berlebihan, ketika seseorang tersebut melakukan aktivitas berat maupun aktivitas sehari-hari. Serta dapat menghindarkan dari berbagai macam penyakit sedini mungkin. Kegiatan bentuk aktivitas fisik merupakan suatu kegiatan yang menjadi tanggung jawab orang tua, terutama bagi anak-anak. Orang tua harus sedini mungkin mengedukasi serta mengajak anak-anak untuk melakukan aktivitas ringan, serta melakukan edukasi betapa bermanfaatnya ketika kita melakukan aktivitas olahraga secara rutin. Aktivitas fisik harus dikenalkan pada anak sedini mungkin, adapun yang memiliki peran sentral pada proses pengenalan berbagai aktivitas fisik adalah keluarga dan orang tua. Apabila orang tua memberikan edukasi sedini mungkin, maka hal ini dapat mempengaruhi gaya hidup sehat melalui berbagai aktivitas fisik sepanjang hayatnya (Nurcahyo, 2011). 
Pada lingkup sekolah ataupun di luar lingkungan keluarga, aktivitas fisik merupakan sebuah kewajiban dibawah tanggung jawab tenaga pendidik ataupun guru di sekolah. Tenaga pendidik atau guru hendaknya memberikan contoh bagaimana melakukan aktivitas olahraga yang mudah dilakukan berdasarkan jenjang usia anak, selain itu proses yang harus ditambahan adalah melakukan edukasi dengan cara mengajarkan apa saja manfaat ketika kita melakukan aktivitas secara optimal, benar dan rutin. Melalui cara tersebut dapat menanamkan kebiasaan kebiasaan yang dapat memberikan kebermanfaatan baik fisik, serta membuat anak selalu bergembira dalam melakukan setiap kegiatan sehari-hari (Burhaein, 2017).

Pelaksanaan aktivitas fisik sendiri melibatkan pemanfaatan otot rangka dalm proses pelaksanaannya, dalam pelaksaan gerak aktivitas fisik tersebut memutuhkan sangat banyak energi jika dibandingkan dengan masa istirahat. Pelaksanaan aktivitas fisik sangat banyak memanfaatkan kesediaan energi yang mendukung agar terciptanya keseimbangan dalam pelaksanaanya (Komite Penanggulangan Kanker Nasional, 2019). Beradasarkan penjelasan yang sudah dipaparkan oleh sebagian pakar diatas bisa disimpulkan kalau segala aktivitas fisik yang dilakukan merupakan suatu bentuk perhatian kepada kesehatan rohani dan jasmani berupa menghindarkan dari penyakit kronis serta membuat anak-anak menjadi lebih sehat dan bugar yang berguna untuk menunjang kegiatan anak-anak sehari-hari manusia, selain itu aktivitas fisik merupakan suatu kegiatan yang dilaksanakan dengan cara memaksimalkan waktu luang dengan cara kegiatan fisik. Bahkan manfaat aktivitas fisik juga dapat membantu anak-anak lebih fokus dalam menerima pelajaran di sekolah (Furqaani, 2017).

Dalam perspektif pada anak usia yang sedang berkembang, aktivitas fisik merupakan suatu kegiatan yang harus terus dipenuhi oleh anak. Karena pada usia tersebut merupakan usia emas perkembangan, perkembangan yang optimal harus dirangsang oleh berbagai kegiatasn aktivitas fisik dan berbagai kegiatan fisik tersebut harus memperhatikan gizi yang cukup dan aktivitas fisik dilakukan secara benar (Burhaein, 2017). Konsentrasi merupakan suatu kemampuan sesorang untuk fokus pada saat mengerjakan sebuah kegiatan hingga selesai pada saat waktu tertentu sehingga seseorang tersebut mampu mengingat secara baik semua pekerjaan yang sedang berlangsung (Manurung \& Simatupang, 2019). Selaras dengan pendapat yang telah dikemukakan diatas mengenai esensi dari konsentrasi. Menurut (Tangkudung \& Mylsidayu, 2017) konsentrasi adalah sebuah kemampuan seseorang untuk bisa mempertahnkan fokus mengenai kegiatan yang terdapat pada suasana berubah secara cepat di pikirannya mengenai masa lalu dan depan.

Arti dari sebuah konsentrasi terutama pada kehidupan sehari-hari sangatlah penting, adapun pada bentuk aktivitas yang memerlukan konsentrasi yang tinggi maupun tidak. Pada kegiatan olahraga, konsentrasi sangatlah berguna dan sangat mendasar, baik pada saat kegiatan yang bertajuk latihan maupun kegiatan olahraga yang bertajuk perlombaan dan pertandingan. Karena apabila atlet tidak konsentrasi sedetikpun dapat membuat perbedaan pada hasil pertandingan. Artinya untuk menghasilkan prestasi yang maksimal, konsetrasi merupakan salah satu bentuk ilmu 
psikologi yang sangat diperlukan untuk mempersiapkan dan menghadapi pertandingan olahraga. Hal ini didukung oleh pendapat yang telah dikemukakakn oleh (Yazid et al., 2016) konsentrasi pada dunia olahraga memiliki konteks yakni suatu proses pemberian perhatian yang maksimal pada sebuah kompetisi yang sedang maupun akan berlangsung, prestasi yang maksimal berasal dari pemusatan konsetrasi yang maksimal oleh atlet. Selaras beradasarkan pendapat yang telah dikemukakan diatas yang mayoritas telah menyampaikan betap pentingnya konsentrasi pada rumpun ilmu olahraga secara khusus. Pada saat pertandingan berlangsung sangat diperlukan konsentrasi tinggi, dengan begitu atlet dapat melakukan segala bentuk gerakan yang efektif, serta maksimal (Hidayat, 2015).

Berdasarkan beberapa pendapat diatas, dapat ditarik kesimpulan betapa pentingnya konsentrasi. Baik pada saat melakukakan kegiatan sehari-hari pada umumnya maupun pada saat terkhusus melakukan aktivitas olahraga supaya dapat menampilkan kemampuan yang maksimal. ada banyak bentuk stimulus yang dapat dilakukan untuk meningkatkan konsentrasi seseorang, diantaranya adalah melakukan olahraga renang bagi anak-anak. Renang merupakan salah satu bentuk aktivitas fisik berupa olahraga yang dilaksanakan di kolam renang dengan cara menggerakan seluruh anggota tubuh dengan tujuan untuk berpindah dari suatu tempat maupun untuk mempertahankan tubuh supaya tetap mengapung diatas permukaan air, olahraga renang memerlukan konsentrasi yang optimal sehingga secara memerlukan konsetrasi yang tinggi pada saat melakukakannya

Renang merupakan salah satu bentuk kegiatan olahraga yang digemari semua jenjang usia, terutama anak-anak. Olahraga renang memberi dampak baik bagi kesehatan, melalui kegiatan aktivitas renang yang rutin dan berkala, akan berimplikasi memperkuat otot serta memperlancar peredaran darah. Hal ini diakibatkan oleh pergerakan seluruh anggota tubuh pada saat seseorang melakukan aktivitas olahraga renang (Hasmarita \& Septiana, 2019). Olahraga renang memiliki ciri khas nya tersendiri yang membedakan dengan kegiatan olahraga pada umumnya, karena olahraga ini tidak dilakukan di lapangan, melainkan olahraga ini dilakukan di air. Peta persebaran masyarakat yang menyukai olahraga renang pun di seluruh indonesia sangat banyak dan dominan, hal ini pun didukung oleh ciri khusus negara kita yakni kepulauan, oleh karena itu renang merupakan bukan merupakan kegiatan yang asing bagi masyarakat di indonesia selain itu karena olahrag renang memiliki banyak manfaat bagi kesehatan (Hasmarita \& Septiana, 2019). Berdasarkan banyak penjelasan yang telah dismapaikan diatas, dapat disimpulkan bahwa, olahra renang merupakan salah satu bentuk aktivitas fisik yang dilakukan di atas permukaan air dilakukan dengan cara menggerakan seluruh anggota tubuh dengan tujuan untuk berpindah tempat maupun sebagai usaha untuk memepertahankan supaya tetap mengapung.

Hubungan antara konsentrasi dan kegiatan aktivitas renang berdasarkan observasi yang telah dilakukan sebagai penggali masalah yang ada pada atlet muda ialah pada saat pelaksanaan aktivitas renang, atlet seringkali mengalami penurunan konsentrasi yang disebabkan banyak faktor, oleh karena itu hal ini bertolak belakang pada konsep 
olahraga renang sendiri yakni berguna untuk meningkatkan konsentrasi, beranjak dari masalah tersebut maka didapatilah judul sebagai berikut. maka penulis tertarik untuk menganalisa tingkat konsentrasi atlet renang dengan judul "Analisis Tingkat Konsentrasi Anak Usia 11-13 Tahun Melalui Aktivitas Fisik Olahraga Renang”.

\section{METODE}

Penelitian berikut memiliki tujuan mengetahui tingkat konsentrasi tingkat konsentrasi anak usia 11-13 tahun terhadap olahraga renang. Penelitian berikut adalah kategori penelitian survei dengan konsep penelitian deskriptif kuantitatif, pada penelitian survey media pengumpulan data memanfaatkan kuisioner yang berisi pertanyaan (Siyoto \& Sodik, 2015). Konsep peneltiain deskriptif adalah sebuah konsep penelitian dengan cara mendeksripsi data-data yang telah dikumpulkan sehingga dapat menyimpulkan hasil dari penelitian (Winarno, 2013).

Populasi penelitian adalah keseluruhan subjek pada penelitian. Populasi pada penelitian yakni total keseluruhan anak yang mengikuti club renang Cimahi Junior Swimming Club yang berusia 11-13 tahun yang berjumlah 15 anak. Menurut (Siyoto \& Sodik, 2015), sampel adalah total sebagian dari populasi yang diambil melalui cara atau prosedur yang berlaku, sehingga sampel yang diambil dapat mewakili total keseluruhan dari jumlah populasi. Adapun sampling pada riset ini ialah menggunakan metode total sampling, melalui metode total sampling didaptilah seluruh jumlah populasi dijadikan sebagai sampel penelitian. Sampel dalam penelitian ini berjumlah 15 anak. Instrumen penelitian ini menggunakan angket konsentrasi, angket tersebt berisi 30 pernyataan dengan menggunakan skala likert. Berikut ini tabel penilaian dalam memberikan skor atau poin pada angket:

Tabel 1. Skala Likert

\begin{tabular}{lcc}
\hline \multicolumn{1}{c}{ Kategori } & $\begin{array}{c}\text { Pernyataan } \\
\text { Positif }\end{array}$ & $\begin{array}{c}\text { Pernyataan } \\
\text { Negatif }\end{array}$ \\
\hline Sangat Setuju & 5 & 1 \\
Setuju & 4 & 2 \\
Ragu-Ragu & 3 & 3 \\
Tidak Setuju & 2 & 4 \\
Sangat Tidak Setuju & 1 & 5 \\
\hline
\end{tabular}

Sumber: (Sugiyono, 2012)

Angket yang telah dibuat, sebelumnya melalui proses uji validitas dan uji realibilitas instrumen. Uji validitas dan reliabilitas menggunakan teknik cronbach's alpha. Teknik analisis data yang digunakan pada penelitian ini yakni menggunakan teknik analisis statistik deskriptif supaya bisa mengetahui tendensi dari temuan penelitian ini sehingga dapat ditetapkan masuk dalam kategori tingkat konsentrasi anak. Rumus interval menurut (Sudibyo, 2011) pengkategorian yang acuannya pada skor mean dan standart deviation yaitu sebagai berikut: 
Tabel 2. Rumus Pengkategorian

\begin{tabular}{ccc}
\hline No & Rumus Interval & Kategori \\
\hline 1 & $\mathrm{X}>(\mathrm{M}+1,5 \mathrm{SD})$ & Sangat Tinggi \\
2 & $(\mathrm{M}+0,5 \mathrm{SD})<\mathrm{X}<(\mathrm{M}+1,5 \mathrm{SD})$ & Tinggi \\
3 & $(\mathrm{M}-0,5 \mathrm{SD})<\mathrm{X}<(\mathrm{M}+0,5 \mathrm{SD})$ & Sedang \\
4 & $(\mathrm{M}-1,5 \mathrm{SD})<\mathrm{X}<(\mathrm{M}-0,5 \mathrm{SD})$ & Rendah \\
5 & $\mathrm{X}<(\mathrm{M}-1,5 \mathrm{SD})$ & Sangat Rendah \\
\hline Keterangan & \\
$\mathrm{X}$ & $:$ Skor & \\
$\mathrm{M}$ & $:$ Mean hitung & \\
SD & $:$ Standar deviasi hitung
\end{tabular}

\section{HASIL}

Hasil penelitian yang telah didapatkan oleh peniliti kemudia dijelaskan secara detail melalui variabel yang ada hubungan. Adapun pembahasan variabel tersebut diakumulasikan melalui data kuntitatif, adapun data tersebut adalah berupa angka serta skor yang ditafsirkan dengan cara deskripsi. Hasil uji validitas didapatkan nila sig 0.00 maka dapat dikatakan jika angket yang digunakan pada penelitian ini adalah valid, serta uji reliabilitas menggunakan teknik cronbach's alpha dengan hasil yaitu sig 0.830 maka dapat dikatakan jika angket yang digunakan bersifat reliabel. berikut Hasil pengukuran tingkat konsentrasi dalam penelitian ini, yaitu sebagai berikut:

Tabel 3. Distribusi Frekuensi Tingkat Konsentrasi

\begin{tabular}{lcc}
\hline & Frequency & Percent \\
\hline Sangat Rendah & 3 & 20 \\
Rendah & 8 & 54 \\
Sedang & 2 & 13 \\
Tinggi & 2 & 13 \\
Sangat Tinggi & 0 & 0 \\
Total & 15 & 100 \\
\hline
\end{tabular}

Berdasarkan tabel 3 distribusi frekuensi tingkat konsentrasi dalam penelitian ini, didapatkan hasil bahwa sampel dalam penelitian ini terdiri dari kategori sangat rendah sebanyak 3 orang, rendah sebanyak 8 orang, sedang sebanyak 2 orang, tinggi sebanyak 2 orang, dan kategori sangat tinggi sebanyak 0 orang. Maka rata-rata tingkat konsentrasi anak usia 11-13 tahun melalui aktivitas fisik olahraga Renang yaitu dalam kategori rendah.

\section{PEMBAHASAN}

Berdasarkan penelitian yang telah dilakukan, ditemukan hasil bahwa terdapat penurunan tingkat konsentrasi anak (atlet) usia 11-13 tahun melalui aktivitas fisik olahraga renang dengan nilai signifikansi konsentrasi atlet usia 11-13 tahun ke dalam kategori rendah. Berdasarkan hasil yang ditemukan terdapat hasil mengenai tingkat 
konsentrasi anak-anak usia 11-13 tahun pada saat melakukan aktivitas fisik melalui kegiatan renang, ada banyak faktor yang menyebabkan konsentrasi anak-anak menurun. Salah satu faktornya adalah mengingat ciri khas yang dimiliki oleh olahraga renang sendiri yakni membutuhkan energi yang cukup banyak untuk melakukan setiap gerakan renang, terutama menggerakan seluruh anggota tubuh pada saat melakukan aktivitas renang. Hal ini memiliki taraf korelasi terhadap lamanya proses aktivitas fisik olahraga renang berlangsung. Melalui persiapan yang belum matang dilakukan oleh anak-anak usia 11-13 tahun, maka dapat membuat konsentrasi anak-anak menurun.

Namun disisi lain olahraga renang melalui olahraga renang yang optimal dan dilakukan secara rutin, dapat memberikan manfaat pada peningkatan kebugaran jasmani serta dapat memperlancar aliran darah. Aktivitas fisik yang direncanakan dengan matang dan memperhatikan lamanya proses berlangsung aktivitas renang dapat memiliki pengaruh di lobus frontalis, bagian dari otak yang berfungsi pada konsentrasi orak, serta memikirkan suatu perencanaan (Coe et al., 2012). Penelitian ini didukung oleh proses penyatuan antara data yang ada di lapangan melalui proses wawancara secara langsung pada pelatih club renang cimahi junior swimming club di lapangan. Hasilnya adalah terdapat perlu pengembangan program yang menyeluruh untuk mengakomodasi proses latihan, pengembangan tersebut meliputi program latihan yang dirancang untuk dapat meningkatkan konsentrasi anak-anak pada saat melakukan aktivitas fisik renang, mengingat konsentrasi pada usia anak-anak relatif stabil dan berubah-ubah, seperti dikemukakan oleh (Hurlock, 2012). Paling utama pada anak yang sedang mengalami proses perkembangan yakni ketika usia 11-13 tahun, hal ini mengingat belum siap nya anak-anak untuk menerima beban latihan yang cukup berat.

Secara tidak langsung aktivitas fisik memiliki repleksi bahwa melalui aktivitas fisik dapat meningkatkan kebugaran seseorang. Pada usia remaja, sangat banyak aktivitas-aktivitas yang dapat mempengaruhi ke arah perbuatan distrubtif, oleh karena itu. Orang tua hendaknya menyalurkan hobi anak-anak mereka melalui kegiatan aktivitas fisik, selain itu. Melalui aktivitas fisik juga dapat membuat mental anak menjadi mental seorang pemenang, dan pekerja keras. Terutama disalurkan melalui aktivitas fisik olahraga beregu maupun individu (Ermona \& Wirjatmadi, 2018).

Berenang merupakan olahraga yang banyak digemari seluruh lapisan masyarakat tanpa dibatasi perbedaan usia, jenis kelamin, pendidikan serta tingkat ekonomi masyarkat. Mengingat negara Indonesia merupakan negara kepulauan yang banyak dikelilingi perairan baik itu sungai maupun laut. Oleh sebab itu tidak heran bila banyak warga di indonesia dapat melakukan aktivitas renang, bahkan banyak juga masyarakat yang sadar untuk mengisi waktu luang mereka untuk melakukan aktivitas yang dapat memberikan manfaat bagi kesehatan melalui aktivitas renang. Hal ini didukung oleh pendapat yang dikemukakan (Susanto, 2010) olahraga renang sangat digemari oleh semua masyarakat diakrenakan olahraga ini memlibatkan seluruh anggota tubuh pada proses pelaksnaannya, melalui aktivitas tersebut dapat memberikan manfaat meningkatnya kebugaran seseorang. Olahraga renang merupakan olahraga yang dilakukan dengan cara menggerakan seluruh anggota tubuh sebagai usaha untuk 
berpindah dari suatu tempat ke tempat lain maupun sebagai usaha untuk tetap terapung di atas permukaan air.

Sama halnya dengan aktivitas olahraga yang lainnya, renang memiliki banyak manfaat, diantaranya adalah: 1) dapat meminimalisirkan tingkat stress, 2) meningkatkan percaya diri, 3) meningkatkan kemampuan kinerja otak, 4) menunda proses penuaan dini, 5) meningkatkan kebugaran jasmani (Sriningsih, n.d.). Manfaat dari aktivitas renang pada secara khusus juga didukung oleh pendapat yang dikemukakakan oleh (Zalni et al., 2018) bahwa melalui aktifitas fisik secara berkala bisa memiliki kontribusi banyak kebermanfaatan dapat menghindarkan dari penyakit degeneratif, penyakit jantung hipertensi maupun diabetes. Peningkatan kemampuan VO2 Max serta peningkatan kebugaran jasmani seseorang didukung oleh berbagai teknik dasar yang ada pada pelaksanaan renang, selain itu melalui teknik yang dilakukan dengan cara benar juga bisa meningkatkan daya kerja jantung serta memperlancar proses aliran darah. Olahraga renang pada dasarnya sama halnya dengan olahraga lain jika ditinjau pada kelelahan yang dialami oleh seseorang. Namun tingkat kelelahannya sedikit lebih lelah hal ini dikarenakan proses adaptasi pernafasan yang sebelumnya bebas untuk menarik nafaas, namun jika pada saat melakukan aktivitas renang, seseorang harus lebih menyeimbangkan antara melakukan aktivitas gerak serta proses pernafasan.

Dengan begitu lelahnya olahraga renang, secara otomatisasi dapat menurunkan konsentrasi seseorang. Hal ini didukung oleh pendapat yang dikemukakan oleh (Gustian, 2016) beberapa faktor yang dapat menurunkan konsentrasi seseorang, diantaranya adalah: terbagi menjadi faktor internal dan faktor eksternal. Faktor internal meliputi seseorang masih memikirikan kejadian pada masa lampau maupun masa yang akan datang, kelelahan pada saat melakukan aktivitas fisik, terlalu memikirkan mekanisme tubuh serta kurangnya motivasi dari dalam seseorang. Faktor eksternal meliputi terganggunya pengeliahtan dan pendengaran seseorang pada saat melakukan aktivitas fisik. Penelitian yang berjudul analisis tingkat konsentrasi atlet usia 11-13 tahun ini bertujuan untuk menganalisis bagaimana tingkat konsentrasi anak-anak pada saat melakukan aktivitas renang, adapaun hasilnya adalah kurangnya tingkat konsentrasi anak-anak.

Adapun hasil penelitian ini dapat dijadikan sebagai informasi untuk para pelatih pada Cimahi Swimming Club untuk dapat mengevaluasi ataupun meningkatan program latihan yang sesuai dengan tumbuh kembang anak-anak, sehingga dapat menghasilkan tujuan yang maksimal, selain itu infromasi ini berguna supaya para pelatih dapat selalu tetap mengawasi para anak-anak dalam melakukan aktivitas renang, mengingat tingkat konsentrasi rata-rata pada anak pada Club Renang Cimahi Swimming club rata-rata rendah. Riset yang dilakukan ini didukung teori- teori serta penelitian- penelitian terdahulu yang sudah dilakukan (Mardliyah et al., 2015) menunjukan bahwa terdapat hubungan tingkat konsentrasi terhadap aktivitas renang pada anak, baik itu konsentrsai yang menurun maupun tingkat konsentrasi yang meningkat. Selanjutnya adalah manfaat dari aktivitas renang yang dikemukakan oleh (Susanto, 2020) adalah melalui olahraga renang dapat meningkatkan kesehatan serta kreativitas dan mental seseorang. Hal ini 
dikarenakan melalui olahraga renang dapat meningkatkan kadar oksigen pada otak serta dapat memperlancar peredaran darah. Pada sisi lain, olahraga dapat mengurangi stress, hal ini terjadi karena olahraga melalui aktivtas olahraga dapat membantu seseorang berpikir rileks dan lebih nyaman dalam proses berpikir untuk kedepannya.

Latihan aerobic bisa tingkatkan keterampilan jantung serta membuat badan lebih cepat menanggulangi stress. Menaikan energi tahan tubuh, gemar melaksanakan berolahraga walaupun tidak sangat lama tetapi kerap dengan bebas melaksanakannya, hingga kegiatan itu dapat tingkatkan hormon- hormon semacam adrenalin, serotonin, dopamine, serta endorphin. Aktifitas fisik amat berarti buat perkembangan kemajuan secara totalitas pada anak. Memaksimalkan kemampuan keahlian serta tindakan yang bisa menimbulkan sikap yang lebih sehat dalam hidup, serta pula menyediakan kemajuan kognitif serta sosial, kemajuan fisiologis yang unik serta pengembangan neurologis kepada anak. Penelitian mengenai kejadian aktifitas raga golongan kanakkanak membuktikan anggapan kalau, selaku anak- anak, mereka menghasilkan gerak mereka sendiri. Begitu pula, orang lanjut usia serta pengasuh nampaknya berasumsi kalau kegiatan fisik diadakan lewat aktivitas bermain diberbagai tempat, sebagai kemajuan motorik agresif serta halus anak, dan kegiatan itu berikan dorongan perkembangan besaran- otot anak, selaku kesiapan umur remaja (Burhaein, 2017).

Konsentrasi bisa ditingkatkan dengan mengelola pernafasan, memanfaatkan perangsangan disaat latihan, memanfaatkan kata- kata isyarat, serta menciptakan kebiasaan berlomba (Gustian, 2016). Berikutnya konsentrasi bisa pula bisa dipulihkan kembali dengan metode istirahat tidur akibatnya tubuh dalam kondisi fit serta bisa tingkatkan fokus olahragawan. Kualitas tidur diduga mempunyai kedudukan yang amat berarti pada situasi fisik serta psikologis seorang. Perihal ini didasarkan oleh peranan tidur itu sendiri, dimana tidur dipercayai membolehkan badan buat memulihkan dirinya sendiri, pengaruhi penyeimbang hormon-hormon dalam badan, memperbaiki ataupun mengistirahatkan fisik sesudah seharian beraktifitas, kurangi stress serta keresahan, memulihkan sel-sel tubuh yang cacat, menyimpan daya, memulihkan kekebalan, termasuk bisa tingkatkan kemampuan daya konsentrasi dikala akan melaksanakan kegiatan setiap hari (Sastrawan \& Griadhi, 2017).

\section{KESIMPULAN}

Berenang merupakan kegiatan aktivitas fisik olahraga yang sangat bermanfaat bagi manusia dalam segi kebugaran tubuh dan kesehatan. Olahraga berenang juga dapat meningkatkan daya tahan seseorang, disebabkan oleh olahraga renang ialah kegaiatan aktifitas fisik yang menggerakan seluruh anggota badan secara keseluruhan. Melalui aktivitas yang sangat berat tersebut dan dilakukan oleh anak-anak usia 11-13 tahun dapat mengalami kelelahan yang berlebihan, oleh karena itu tingkat kesadaran seseorang yang tertuju pada suatu objek dapat menurun. Terdapat banyak faktor yang menyebabkan menurunnya konsentrasi seseorang, diantaranya adalah faktor kesiapan anak usia 11-13 tahun untuk mempersiapkan tubuhnya dalam melakukan aktivitas 
renang, selain itu yang harus diperhatikan supaya konsentrasi anak tidak menurun adalah menurunkan indeks beban latihan yang diberikan.

Berdasarkan penjelasan diatas dan telah mempertimbangkan melalui analisis data berupa test konsentrasi pada anak-anak yang mengikuti renang di Club Cimahi Junior Swimming Club, maka dapat ditarik kesimpulan bahwa tingkat konsentrasi anak usia 11-13 tahun pada saat melakukan aktivitas renang tergolong pada kategori rendah.

\section{DAFTAR PUSTAKA}

Burhaein, E. (2017). Aktivitas fisik olahraga untuk pertumbuhan dan perkembangan siswa SD. Indonesian Journal of Primary Education, 1(1), 51-58.

Coe, D. P., Pivarnik, J. M., Womack, C. J., Reeves, M. J., \& Malina, R. M. (2006). Effect of physical education and activity levels on academic achievement in children. Medicine and Science in Sports and Exercise, 38(8), 1515.

Ermona, N. D. N., \& Wirjatmadi, B. (2018). Hubungan aktivitas fisik dan asupan gizi dengan status gizi lebih pada anak usia sekolah dasar di SDN Ketabang 1 Kota Surabaya tahun 2017. Amerta Nutrition, 2(1), 97-105.

Furqaani, A. R. (2017). Latihan fisik sebagai brain booster untuk anak. Golden Age: Jurnal Pendidikan Anak Usia Dini, 1(1).

Gustian, U. (2016). Pentingnya Perhatian dan Konsentrasi dalam Menunjang Penampilan Atlet. Jurnal Performa Olahraga, 1(01), 89-102.

Haryanto, J., \& Welis, W. (2019). Minat Berolahraga pada kelompok usia middle age. Jurnal Performa Olahraga, 4(2), 214-223.

Hasmarita, S., \& Septiana, R. A. (2019). Hubungan kepercayaan diri dengan teknik dasar grab start. Journal of Physical and Outdoor Education, 1(1), 63-72. https://doi.org/10.37742/jpoe.v1i2.11

Hidayat, Y. (2009). Pengantar Psikologi Olahraga. Bandung: CV Bintang Warli Artika.

Hurlock, E. B. (1994). Perkembangan Anak; Jilid 1.

Manurung, M. P., \& Simatupang, D. (2019). Meningkatkan Konsentrasi Anak Usia 5-6 Tahun Melalui Penggunaan Metode Bercerita di TK ST Theresia Binjai. Jurnal Usia Dini, 5(1), 58-75.

Mardliyah, A., Candrawati, S., \& Nimalasari, D. (2015). Hubungan Renang dengan Konsentrasi pada Anak. Mandala of Health, 8(3), 608.

Nurcahyo, F. (2011). Kaitan antara obesitas dan aktivitas fisik. Medikora, 1.

Pranata, D., Hartati, H., Afrizal, A., \& Victorian, A. R. (n.d.). Pengembangan Model 
Aplikasi Tes Fisik Cabang Olahraga Bola Voli Pada Pusat Pendidikan dan Latihan Pelajar Daerah (PPLPD) Kabupaten Musi Banyuasin. Journal Physical Education, Health and Recreation, 3(2), 105-111.

Sastrawan, I. M. A., \& Griadhi, I. P. A. (2017). Hubungan Antara Kualitas Tidur dan Daya Konsentrasi Mahasiswa Program Studi Pendidikan Dokter Fakultas Kedokteran Universitas Udayana. E-Jurnal Medika, 6(8), 2-8.

Sholihin, A. D. (2015). Analisis Aktivitas Fisik Dan Aktivitas Belajar Pada Mahasiswa Fakultas Ilmu Keolahragaan Universitas Negeri Semarang Dalam Memanfaatkan Waktu Luang. Journal of Sport Science and Fitness, 4(4), 34-37.

Siyoto, S., \& Sodik, A. (2015). Dasar Metodologi Penelitian (Ayup (ed.)). Literasi Media Publishing.

Sriningsih, S. (n.d.). Keterampilan Renang Gaya Kupu-Kupu melalui Pendekatan Bermain dalam Pembelajaran Akuatik. Jurnal Pendidikan Jasmani Dan Olahraga, 2(2), 43-52.

Sudibyo, S. (2002). Psikologi Olahraga. Jakarta: Universitas Negeri Jakarta.

Sugiyono, D. (2010). Metode penelitian kuantitatif dan R\&D. Bandung: Alfabeta.

Susanto. (2020). Pengaruh virus covid 19 terhadap bidang olahraga di indonesia. $M$ odos de Ver, 21(1), 1-9. https://doi.org/10.1016/j.solener.2019.02.027

Susanto, E. (2020). Manfaat Olahraga Renang Olahraga Renang Olahraga Renang Bagi Lanjut Usia Bagi Lanjut Usia. http://staff.uny.ac.id/sites/default/files/197807022002121004/2.\%20Manfaat\%20 Olahraga\%20Renang\%20bagi\%20Lanjut\%20Usia,\%20Jurnal\%20MEDIKORA,\% 20Volume\%20VI,\%20Nomor\%201,\%20April\%202010_0.pdf.

Tangkudung, J., \& Mylsidayu, A. (2017). Mental Training Aspek-Aspek Psikologi dalam Olahraga. Bekasi: Cakrawala Cendikia.

Winarno. (2013). Metodologi Penelitian Dalam Pendidikan Jasmani (Issue January). UM Press.

Yazid, S., Kusmaedi, N., \& Paramitha, S. T. (2016). Hubungan Konsentrasi Dengan Hasil Pukulan Jarak Jauh (Long Sroke) Pada Cabang Olahraga Woodball. Jurnal Terapan Ilmu Keolahragaan, 1(1), 50. https://doi.org/10.17509/jtikor.v1i1.3903

Zalni, R. I., Harahap, H., \& Desfita, S. (2018). Usia Menarche Pada Anak Perempuan Berhubungan Dengan Status Gizi, Konsumsi Makanan Dan Aktivitas Fisik. 